\title{
Conjoint Analysis for Evaluation of Customer's Preference of Analgesic Generic Medicines under Non-proprietary Names
}

\author{
Aries Susanty*, Bambang Purwanggono, Nia Budi Puspitasari, Chellsy Allison \\ Department of Industrial Engineering, Diponegoro University, Semarang - Indonesia
}

\begin{abstract}
The main objective of this research is to get greater insight into the customer preferences in purchasing analgesic generic medicines under the non-proprietary name and to identify clusters with different preference structures. This research uses conjoint analysis (CA) and cluster analysis as data processing. This research collects the data through questionnaire from 200 respondents and uses the convenience sampling method to choose 200 respondents from sixteen districts in Semarang. The result of data processing with conjoint analysis indicated that customer prefers the analgesic generic medicine under the non-proprietary name with the following condition: the price of $20 \%$ of analgesic generic-branded minutes, has 15 minutes onset time of effect, can be purchased at minimarket, in the form of syrup, and the source of information is family and friend. Moreover, the result of data processing also indicated that the importance of attribute is the place of purchase, followed by price, onset time of drugs, the form of drugs, and, the source of information. Then, the result of data processing with clustering analysis indicated that the respondent can be grouped into four clusters. The attribute that has the highest importance level in cluster 1 until cluster 4 is 'form of drugs', 'the place of purchase', 'source of information', and 'price', respectively.
\end{abstract}

Keywords. sustainability index of economic; sustainability index of environmental; sustainability index of social; multi-grade fuzzy; CV. Indo Jati Utama.

\section{Introduction}

The economic burden on drug budgets has increased in the use of generic medicines [1] as those medicines typically $20 \%$ to $90 \%$ cheaper than originator equivalents [2]. In this case, the usage of inexpensive generic medicines is frequently promoted as a measure to decrease the health care expenses on the pharmaceutical products, and afford savings to patients as well as governments. The definition of generic medicine can be varied in different countries.

* Corresponding author: ariessusanty@gmail.com 
However, the term is commonly understood, as defined by the World Health Organization. Generic medicine is "a pharmaceutical product, usually intended to be interchangeable with an innovator product that is manufactured without a license from the innovator company and marketed after the expiry date of the patent or other exclusive rights" [3].

It can be said that the generic medicines are those where patent protection has finished, and which may be manufactured by other companies than the innovator [2]. A generic medicine is a duplicate of brand-name counterpart as the FDA requires that a generic drug have similar dosage, form, safety, quality, strength, performance, mode of administration, and intended to use. Based on this condition, generic medicines have the same benefits and risks as their brand-name counterparts [4]. Moreover, the generic medicines can be marketed under a proprietary name ("branded generics") or non-proprietary name [5]. Non-proprietary name is the name for the active ingredient in the medicine that is decided by an expert committee and understood internationally [6]. As an example, paracetamol/ acetaminophen are the non-proprietary name (generic name) while Crocin/Metacin/ Meftal/Tylenol etc. are brand names. Paracetamol belongs to non-opioids analgesics drugs which are used for pain relief and one of the commonest medications used worldwide [7]. Despite the increased use of generic medicines, it very limited knowledge about the attitudes of patients towards the generic medicine or the decision-making process surrounding the generic medicine [8]. Generally, groups of younger and more educated consumers were found to be generic medicines purchasers. Consumers' previous negative experience with generic medicines and the perceived degree of risk was reported to have a negative attitude toward generic medicines. The severity of disease conditions also influences consumer decisions to use generic medicines [9]. Moreover, marketing strategies by pharmaceutical companies also affect consumers' attitudes toward generic medicines [4]. Then, according to reference [10], consumer behavior in using the generic medicines is influenced by demographic factors (such as race, gender, age, income, and others), cost, insurance, promotional activities, socialization and education of generic drugs, technology, and medical personnel.

In Indonesia, for certain types of medicines, the public preference in buying generic medicines that marketed under the proprietary name ("branded generics") is higher than generic medicines under the non-proprietary name. This condition can be seen from the market share of those two types of generic medicines in the analgesic group. According to the Director-General of Pharmaceutical and Medical Devices Development, in the analgesic group, the market share of branded generic reached $70 \%$, while the market share of generic medicines under the non-proprietary name was only $10 \%$, and the remainder, as much as $20 \%$ was the market share of patent medicines. The interest of the customer to buy the branded generic medicines is also can be seen from the results of the preliminary study. Compared to the others, the generic medicines belong to the analgesic group are the most widely purchased by the respondents.

The respondents buy generic medicine as the first step before seeing the doctor or going to the hospital. Furthermore, the results of the preliminary study indicated that as much as $60 \%$ of respondents prefer to purchase branded generic medicines compared to generic under non-proprietary, although the price of branded generic medicines more expensive. The respondents choose branded generic medicines as these medicines are easy to found. The generic branded medicines sold anywhere such as minimarkets, supermarkets, food stalls, and pharmacies; while, generic medicines under non-proprietary names only sold in pharmacies. Moreover, the respondent more familiar with the brand of generic branded medicine than generic medicine under the non-proprietary name. The reason for $40 \%$ of respondents who choose generic medicines under the non-proprietary name is cheaper than branded generic medicines, receive recommendations from trusted people such as family, friends, and pharmacists, and the efficacy of the medicines. 
So, based on the phenomenon of purchasing the two type of generic medicine (branded generic medicines and generic medicines under the non-proprietary name) as well as the results of a preliminary study, the main objective of this research is to get the greater insight into the customer preferences in purchasing analgesic generic medicines under the nonproprietary name and to identify clusters of the customers based on their preferences This research will use conjoint analysis (CA) for studying the consumer preferences.

\section{Literature Review-the preferences of the customers}

The preferences of the consumers are a positive motivation, expressed by the affective compatibility towards a product or service [11]. The preferences of the customer is a marketing term that means the probability to select one product or services over another. In economics, preferences of the customers are defined as individual tastes and being measured by the utility of various bundles of goods [12,13]. Psychologically, preferences can be seen as a person's attitude towards a set of objects that stimulates her or his behavior in the process of decision-making [14]. The customer is creating a decision choice in several ways, from the simple decision to a complex decision. It is a process by which customers are gathering related information about the attributes of the products; assess the information according to their preferences before assigning a value to select between alternatives [15]. Moreover, the preferences of the customer for certain products or services arise from the combination of many different factors. Some factors come from features of the product itself (e.g., durability, price), while others are attributes of consumers themselves (e.g., goals, attitudes, discretionary income) [16].

\section{Method of research}

\subsection{The data processing technique}

This research use conjoint analysis (CA) and cluster analysis as a data processing technique.

\section{Conjoint analysis}

Conjoint measurement theory was established in psychology by Luce and Turkey in 1964 and was modified to marketing. Since then, CA has been widely used in marketing to discover how buyers make trade-offs when considering purchase decisions [17]. Recently, CA not only used in the marketing area, but CA has also been used in several service industries, specifically health care [18], education [19, 20], hospitality [21], distribution [22], and total quality management [23].

There were five important steps in CA. First, determine the relevant product attributes that believed to influence the preferences of the customer among different products. This attribute should be relevant to the potential customers and can be influenced or worked by the manufacturer. Second, assign the level to these attributes, which must be reasonable, actionable, and proficient of being traded-off. The select levels should be such that every level of each attribute is similar enough to be a close substitute and dissimilar enough to be ranked or rate. Graphically, the relationship between product attributes and levels can be seen in the following figure. 


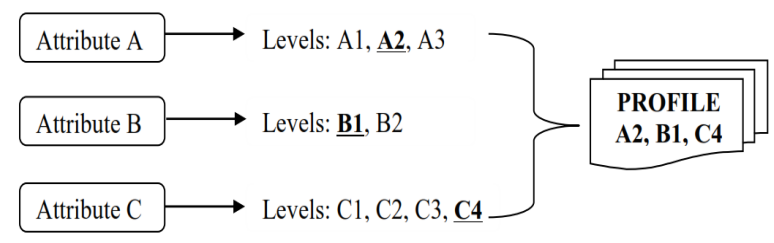

Fig. 1. The relationship between product attribute and levels in conjoint analysis

Third, establish the number of stimuli to be presented to the customer. This is related to the number of possible profiles or the number of possible attribute-level combination to be presented to the customer. Fourth, establish the preferences of the customer through design the questionnaire that consists of a set of attributes and the level of the portfolio of products with the letter detailed description. Fifth, collect the respond of the questionnaire and process the data to modelling the customer preferences [24, 25].

\section{Cluster analysis}

Cluster analysis is a multivariate technique used for the classification of objects based on certain characteristics. The cluster analysis will classify the objects, so the object with similar characteristics will be gathered at the same cluster [26]. In this research, cluster analysis was conducted using the K-means method with aid of the Statistical Package for Social Sciences (SPSS) software and Calinski-Harabasz index $(\mathrm{CH})$ or sometimes was called the variance ratio criterion (VRC) to determine the optimal number of clusters. The $\mathrm{CHI}$ is calculated by dividing the variance between-cluster variance with the variance within-cluster. Then, the optimal number of clusters is the solution with the highest Calinski-Harabasz index value as well-defined clusters will have a large variance between-cluster and a small variance withincluster [27].

\subsection{Establishing the attributes, levels and its combination}

The five main attributes found to influence the preferences of the customer in using generic medicines under the non-proprietary name, namely place of purchase, source of information, medicine form, price, and onset time of effect. Each attribute has several levels, such as place of purchase have four levels, namely pharmacies, kiosks, minimarket, and supermarket. Source of information has three levels, namely health experts (doctor or pharmacist), family and friends, and the internet. Drug form has four levels, namely caplet, pill, capsule, and syrup. Price has three-level namely $60 \%$ of the price of branded-generic medicine, $50 \%$ of the price of branded-generic medicine, $30 \%$ of the price of branded-generic medicine, and $20 \%$ of the price of branded-generic medicine. Last, the onset time of effect has three levels, namely 15 minutes, 25 minutes, and 30 minutes. Those attributes and its level were adopted from Helme et al [8] as well as the results of initial interviews with the users of generic medicine in the analgesic group. Then, the number of scenarios or the combination of attribute levels to be presented to the customer was determined to use Orthoplan subroutine in SPSS, which ensures the absence of multicollinearity between attributes. The sixteen combinations of attribute level which resulted and were used in the research are shown in Table 1. 
Table 1. Combinations of attribute level

\begin{tabular}{|c|c|c|c|c|c|}
\hline No & Price & $\begin{array}{l}\text { Place of } \\
\text { purchase }\end{array}$ & $\begin{array}{c}\text { Source of } \\
\text { information }\end{array}$ & $\begin{array}{l}\text { Medicine } \\
\text { form }\end{array}$ & $\begin{array}{l}\text { Onset time } \\
\text { of effect }\end{array}$ \\
\hline 1 & $\begin{array}{l}20 \% \text { of price of } \\
\text { branded-generic } \\
\text { medicine }\end{array}$ & Supermarket & $\begin{array}{l}\text { Family and } \\
\text { friends }\end{array}$ & Capsule & 15 minutes \\
\hline 2 & $\begin{array}{l}60 \% \text { of price of } \\
\text { branded-generic } \\
\text { medicine }\end{array}$ & Pharmacies & $\begin{array}{l}\text { Health experts } \\
\text { (doctor or } \\
\text { pharmacist }\end{array}$ & Caplet & 15 minutes \\
\hline 3 & $\begin{array}{l}20 \% \text { of price of } \\
\text { branded-generic } \\
\text { medicine }\end{array}$ & Minimarket & $\begin{array}{l}\text { Health experts } \\
\text { (doctor or } \\
\text { pharmacist }\end{array}$ & Pill & 30 minutes \\
\hline 4 & $\begin{array}{l}20 \% \text { of price of } \\
\text { branded-generic } \\
\text { medicine }\end{array}$ & Pharmacies & $\begin{array}{l}\text { Health experts } \\
\text { (doctor or } \\
\text { pharmacist }\end{array}$ & Syrup & 15 minutes \\
\hline 5 & $\begin{array}{l}30 \% \text { of price of } \\
\text { branded-generic } \\
\text { medicine }\end{array}$ & Minimarket & $\begin{array}{l}\text { Family and } \\
\text { friends }\end{array}$ & Caplet & 15 minutes \\
\hline 6 & $\begin{array}{l}30 \% \text { of price of } \\
\text { branded-generic } \\
\text { medicine }\end{array}$ & Kiosks & $\begin{array}{l}\text { Health experts } \\
\text { (doctor or } \\
\text { pharmacist }\end{array}$ & Pill & 15 minutes \\
\hline 7 & $\begin{array}{l}60 \% \text { of price of } \\
\text { branded-generic } \\
\text { medicine }\end{array}$ & Kiosks & $\begin{array}{l}\text { Family and } \\
\text { friends }\end{array}$ & Syrup & 30 minutes \\
\hline 8 & $\begin{array}{l}30 \% \text { of price of } \\
\text { branded-generic } \\
\text { medicine }\end{array}$ & Pharmacies & Internet & Capsule & 30 minutes \\
\hline 9 & $\begin{array}{l}50 \% \text { of price of } \\
\text { branded-generic } \\
\text { medicine }\end{array}$ & Pharmacies & $\begin{array}{l}\text { Family and } \\
\text { friends }\end{array}$ & Pill & 25 minutes \\
\hline 10 & $\begin{array}{l}60 \% \text { of price of } \\
\text { branded-generic } \\
\text { medicine }\end{array}$ & Minimarket & $\begin{array}{l}\text { Health experts } \\
\text { (doctor or } \\
\text { pharmacist }\end{array}$ & Capsule & 25 minutes \\
\hline 11 & $\begin{array}{l}50 \% \text { of price of } \\
\text { branded-generic } \\
\text { medicine }\end{array}$ & Kiosks & $\begin{array}{l}\text { Health experts } \\
\text { (doctor or } \\
\text { pharmacist }\end{array}$ & Capsule & 15 minutes \\
\hline 12 & $\begin{array}{l}20 \% \text { of price of } \\
\text { branded-generic } \\
\text { medicine }\end{array}$ & Kiosks & Internet & Caplet & 25 minutes \\
\hline 13 & $\begin{array}{l}30 \% \text { of price of } \\
\text { branded-generic } \\
\text { medicine }\end{array}$ & Supermarket & $\begin{array}{l}\text { Health experts } \\
\text { (doctor or } \\
\text { pharmacist }\end{array}$ & Syrup & 25 minutes \\
\hline 14 & $\begin{array}{l}60 \% \text { of price of } \\
\text { branded-generic } \\
\text { medicine }\end{array}$ & Supermarket & Internet & Pill & 15 minutes \\
\hline 15 & $\begin{array}{l}50 \% \text { of price of } \\
\text { branded-generic } \\
\text { medicine }\end{array}$ & Supermarket & $\begin{array}{l}\text { Health experts } \\
\text { (doctor or } \\
\text { pharmacist }\end{array}$ & Caplet & 30 minutes \\
\hline 16 & $\begin{array}{l}50 \% \text { of price of } \\
\text { branded-generic } \\
\text { medicine }\end{array}$ & Minimarket & Internet & Syrup & 15 minutes \\
\hline
\end{tabular}




\subsection{Survey instrument}

The questionnaire used in this research contained three main parts. The first part of the questionnaire aims to investigate the background information of the respondents including sex, age, occupation, revenue in a month, and the frequency of medicines purchase in a month. The second part of a questionnaire consisting of 6 items to assess health behaviour of the respondents (look for information, read health articles, have favourite medicines, eat healthy, work out regularly, and consumed vitamin); and the third part of questionnaire consists of sixteen sets of stimuli or attribute-level combination to assess preference ranking. In this case, the first part of the questionnaire is the open-ended questionnaire whereas the second and third part of the questionnaire is a closed-end questionnaire. In the second part of the questionnaire, respondent was asked to state their health behaviour with a seven-point scale use seven-point Likert Scale (from strongly disagree until strongly agree); whereas, in the third part of the questionnaire, respondent was asked to rank the set of stimuli (ranking 1 means the first preferred level and ranking 16 means the lowest preferred level).

\subsection{Sample selection and description}

This research use the formula from Etikan et al [28] to calculate the minimum number of sample.

$$
n=\frac{\left(z \frac{\alpha}{2}\right)^{2} p \cdot q}{e^{2}}
$$

Whereas, $z_{-}(\alpha / 2)$ is the statistical value corresponding to level of confidence required (typical levels of confidence used are 95 percent; its means c equal to 0.05 and the $Z$ value equal to 1.96); $p$ is the percentage of a sample having a certain characteristic and $q$ or (100$\mathrm{p})$ is the respondents who $(100-\mathrm{P})$ is the percentage $(60 \%)$ who lack the characteristic or do not have a certain characteristic; and e is the percentage maximum error required.

So, with the value of $\alpha 0.05$ (or $Z$ value equal to 1.96), the percentage of respondent who purchase the generic medicines under non-proprietary name equal to $40 \%$ (based on the preliminary survey), and the percentage maximum error equal to $10 \%$, the minimum number of sample required is 93 respondents. However, in this research we collect the information from 200 respondents which indicated the sufficiency the number of samples used for this research. Moreover, this research used convenience sampling method to choose 200 respondents from sixteen district in Semarang. In detail, the number of samples from each district in Semarang can be seen in Table 2.

Table 2. The Number of Respondents in Each District in Semarang

\begin{tabular}{|c|l|c|c|l|c|}
\hline No & \multicolumn{1}{|c|}{ Districts } & $\begin{array}{c}\text { Number of } \\
\text { Respondents }\end{array}$ & No & Districts & $\begin{array}{c}\text { Number of } \\
\text { Respondents }\end{array}$ \\
\hline $\mathbf{1}$ & West Semarang & 15 & 9 & Pedurungan & 17 \\
\hline $\mathbf{2}$ & Middle Semarang & 6 & 10 & Banyumanik & 13 \\
\hline $\mathbf{3}$ & North Semarang & 11 & 11 & Gunungpati & 8 \\
\hline $\mathbf{4}$ & South Semarang & 7 & 12 & Mijen & 6 \\
\hline $\mathbf{5}$ & East Semarang & 7 & 13 & Tembalang & 16 \\
\hline $\mathbf{6}$ & Gayamsari & 7 & 14 & Tugu & 3 \\
\hline $\mathbf{7}$ & Gajah Mungkur & 5 & 15 & Candisari & 7 \\
\hline $\mathbf{8}$ & Genuk & 10 & 16 & Ngaliyan & 12 \\
\hline
\end{tabular}




\section{Result and discussion}

\subsection{Demographic Profile of the Respondent}

Table 3 summarizes the demographic profile of the respondents. It can be seen that respondents consisted of $53.00 \%$ male participants and $47.00 \%$ female participants. Nearly three quarters $(72.00 \%)$ of respondents were between the ages of 23 to 60 , having an occupation as an employee $(43.50 \%)$, others $(34.00 \%)$, college students $(30.00 \%)$, and students $(7.50 \%)$. Approximately $37.50 \%$ of respondents had monthly income more than IDR $5,000,000 ; 33.00 \%$ of respondents had monthly income between IDR 1.000 .000 to IDR 5.000 .000 , and $29.5 \%$ of respondents had monthly income less than IDR $1,000,000$.

Table 3. Demographic Profile of the Respondents

\begin{tabular}{|c|c|c|c|c|c|c|c|}
\hline \multicolumn{2}{|c|}{ Demographic Factor } & \multirow{2}{*}{$\begin{array}{c}\text { Number } \\
106\end{array}$} & \multirow{2}{*}{$\begin{array}{c}\mathbf{\%} \\
53.00 \%\end{array}$} & \multicolumn{2}{|c|}{ Demographic Factor } & \multirow{2}{*}{$\begin{array}{c}\text { Number } \\
59\end{array}$} & \multirow{2}{*}{$\begin{array}{c}\% \\
29.50 \%\end{array}$} \\
\hline \multirow[b]{2}{*}{ Sex } & Male & & & \multirow{3}{*}{$\begin{array}{l}\text { Revenue in } \\
\text { a month }\end{array}$} & $\begin{array}{l}<\text { IDR } \\
1.000 .000\end{array}$ & & \\
\hline & Female & 94 & $47.00 \%$ & & $\begin{array}{l}\text { IDR } \\
1.000 .000- \\
\text { IDR } \\
5.000 .000\end{array}$ & 66 & $33.00 \%$ \\
\hline \multirow[t]{2}{*}{ Age } & $16-22$ & 56 & $28.00 \%$ & & $\begin{array}{l}\text { > IDR } \\
5.000 .000\end{array}$ & 75 & $37.50 \%$ \\
\hline & $23-60$ & 144 & $72.00 \%$ & \multirow{5}{*}{$\begin{array}{l}\text { Frequency } \\
\text { of drugs } \\
\text { purchase in } \\
\text { a month }\end{array}$} & \multirow{3}{*}{$1-3$ time } & \multirow{3}{*}{161} & \multirow{3}{*}{$80.50 \%$} \\
\hline \multirow{4}{*}{ Occupation } & Student & 15 & $7.50 \%$ & & & & \\
\hline & $\begin{array}{l}\text { College } \\
\text { Student }\end{array}$ & 30 & $15.00 \%$ & & & & \\
\hline & Employee & 87 & $43.50 \%$ & & \multirow{2}{*}{$>3$ time } & \multirow{2}{*}{39} & \multirow{2}{*}{$19.50 \%$} \\
\hline & Others & 68 & $34.00 \%$ & & & & \\
\hline
\end{tabular}

\subsection{The Results of Conjoint Analysis}

Table 4 shows the utility and relative importance values of each attribute. We found that Pearson's R was 0.966 and Kendall's-Tau was 0.783 which indicated that the overall fit of the model was good. The results confirm that conjoint analysis has good predictability for consumers choosing analgesic generic medicine under the proprietary name

Table 4. The result of conjoint analysis

\begin{tabular}{|l|c|c|c|}
\hline \multicolumn{1}{|c|}{ Attribute and level } & Utility & Std.Error & Relative Importance \\
\hline Place of purchase & & & $29.31 \%$ \\
\hline Pharmacies & 0.749 & 0.511 & \\
\hline Minimarket & 1.461 & 0.511 & \\
\hline Kiosks & -0.771 & 0.511 & \\
\hline Supermarket & -1.439 & 0.511 & \\
\hline Source of information & & & $15.28 \%$ \\
\hline Health experts (doctor/pharmacist) & 0.510 & 0.393 & \\
\hline Family and friends & 0.784 & 0.461 & \\
\hline Internet & -1.294 & 0.461 & \\
\hline Drug form & & & \\
\hline Caplet & 0.245 & 0.511 & \\
\hline Pill & -0.674 & 0.511 & \\
\hline Capsule & 0.174 & 0.511 & \\
\hline Syrup & 0.255 & 0.511 & \\
\hline Price & & & \\
\hline
\end{tabular}




\begin{tabular}{|l|c|c|c|}
\hline \multicolumn{1}{|c|}{ Attribute and level } & Utility & Std.Error & Relative Importance \\
\hline $60 \%$ of price of branded generic medicines & 1.274 & 0.264 & \\
\hline $50 \%$ of price of branded generic medicines & 2.548 & 0.527 & \\
\hline $30 \%$ of price of branded generic medicines & 3.821 & 0.791 & \\
\hline $20 \%$ of price of branded generic medicines & 5.095 & 1.055 & \\
\hline Onset Time of Effect & & & $16.85 \%$ \\
\hline $15 \mathrm{~min}$ & -1.656 & 0.356 & \\
\hline $25 \mathrm{~min}$ & -3.313 & 0.711 & \\
\hline $30 \mathrm{~min}$ & -4.969 & 1.067 & \\
\hline
\end{tabular}

For each level of each attribute, large part-worth values are assigned to the most preferred levels, and small part-worth values are assigned to the least preferred levels. The part-worth estimates can serve as a basis for predicting the choice probabilities of various combinations of attribute levels [29].

Minimarket is the level in attribute 'place of purchase' that has large-worth value. As the minimarket can be found everywhere [30], this condition indicated that the more easily obtained, the more preferred the consumers to use the generic medicine under the nonproprietary name. Family and friend is the level in attribute 'source of information' that has worth large value. These results state that consumers' trust is affected by those closest to them. These results are the same as the results of previous studies conducted by Halme et al (2009). Then, syrup and caplet are the first and second level in attribute 'form of medicines' that has worth-large value. This condition indicated that the customer wants an analgesic generic medicines under the non-proprietary name that easy to swallow and consumed. Then, $20 \%$ of the price of branded-generic-medicine is the level in the attribute 'price' that has large-worth value. This condition happens since people tend to choose products with low prices. Last, the onset of time effect as much as 15 minutes is the level in attribute 'onset of time effect' that has large-worth value. It is no surprise since the customer prefers the medicines with quick effect. Then, from the part-worth values are assigned to the most preferred levels, customer prefer the analgesic generic medicine under the non-proprietary name with the following condition: the price of $20 \%$ of analgesic generic-branded minutes, has 15 minutes onset time of effect, can be purchased at minimarket, in the form of syrup, and the source of information is family and friends. Moreover, based on the relative importance value for selecting the analgesic generic medicine under the non-proprietary name, 'the place of purchase' is the most preferred factor with a relative importance value $29.31 \%$; it is followed by 'price' $(21.84 \%)$, 'onset time of effect' $(16.85 \%)$, and 'form of drugs $(16.714 \%)$ '. The source of information played a minor role for consumers to purchase analgesic generic medicines under the non-proprietary name.

\subsection{The Results of Cluster Analysis}

The result of cluster analysis of the health behavior of the respondents as well as the relative importance of each attribute of analgesic generic medicine under non-proprietary in each cluster can be seen in Figure1 and Figure 2. This research grouped the respondent into four clusters as the four clusters have higher Calinski-Habarasz Index values than three or five clusters. The value of Calinski-Habarasz Index for three clusters 565.266, four clusters 580.613, and five clusters 521.779. According to Figure 1, it can be seen each cluster was dominated by different health behaviour: loyal to certain types of medicines [cluster 1, 'have a favourite medicine' has value 4.38]; like to exercise [cluster 2, 'work out regularly has value 4.15]; like to exercise as well as eat healthy food, always looking for information and reading health articles [cluster 3, 'work out regularly', 'eat healthy' 'look for information' and 'read health articles,' have value 4.61, 4.42, 4.18, and 4.12 respectively]; always eat healthy food [cluster 4, 'eat healthy' has value 4.13]. Then, related to the relative importance 
of theeach attribute of analgesic generic medicine under non-proprietary name, 'form of drugs' has the highest importance level is indicated that, in cluster 1, This is probably because most of the respondents in cluster 1 are elderly people. There are often found difficulty swallowing in elderly people due to a decrease in their health conditions. Then, it is suspected to be the cause of cluster 1 have a form of the drugs to be an important attribute. The respondents in cluster 2 more consider about 'the place of purchase' the analgesic generic medicine under the non-proprietary name. This can happen since most of the respondents in cluster 2 are employees. They need practical things to get medicine as they do not have time to go to a specific place, especially during business hours. In cluster 3, the attribute 'source of information' has the highest importance level. This is probably because cluster 3 dominates with a respondent who has healthy behaviours by seeking information and reading health articles. In cluster 4, the attribute 'price' has the highest importance level. This is probably because cluster 4 dominate by with respondent who has revenue in a month less than IDR 1.000.000.000.

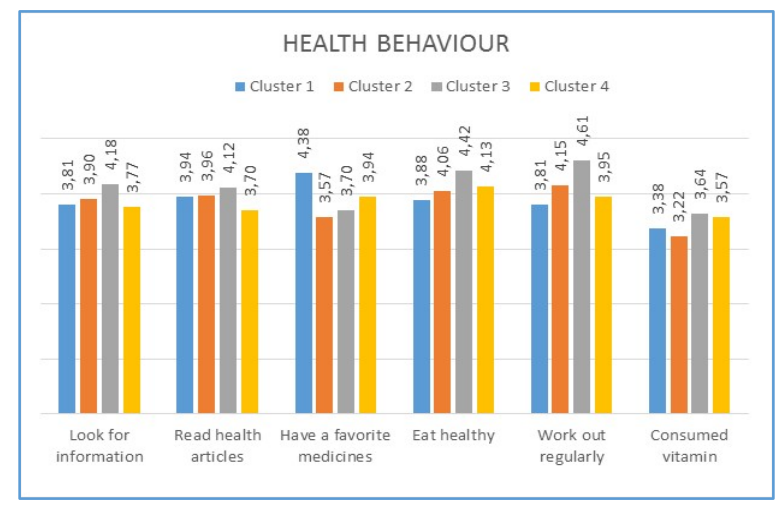

Figure 1. Respondent health behaviour according to their cluster

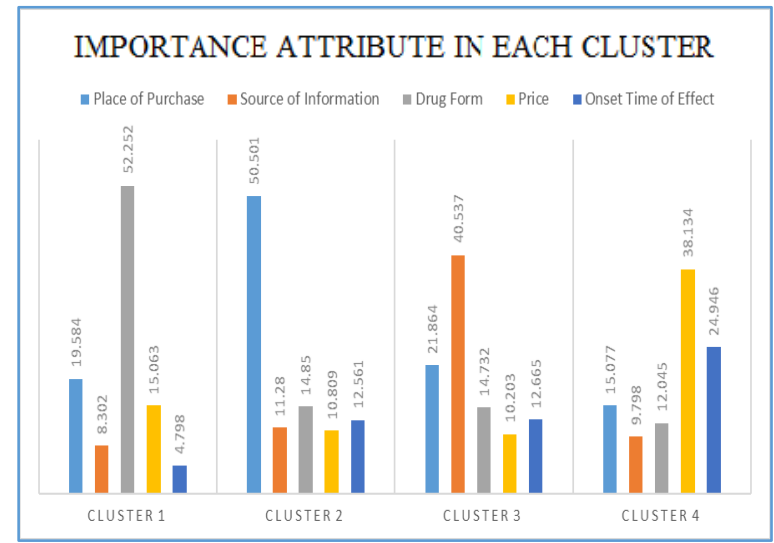

Figure 2. Importance attribute in each cluster 


\section{Conclusion}

The purpose of this study is to determine the customer preferences in purchasing analgesic generic medicines under the non-proprietary name and to identify clusters with different preference structures, The result of data processing with conjoint analysis indicated that customer prefers the analgesic generic medicine under the non-proprietary name with the following condition: the price of $20 \%$ of analgesic generic-branded minutes, has 15 minutes onset time of effect, can be purchased at minimarket, in the form of syrup, and the source of information is family and friend. Moreover, the result of data processing also indicated that the importance of attribute is the place of purchase $(29.310 \%)$, followed by price $(21.843 \%)$, onset time of drugs $(16.849 \%)$, the form of drugs $(16.714 \%)$ and, the last is the source of information (15.284\%). Then, the result of data processing with clustering analysis indicated that the respondent can be grouped into four clusters. The attribute that has the highest importance level in cluster 1 until cluster 4 is the 'form of drugs', 'the place of purchase', 'source of information', and 'price', respectively.

The result of this research gives some recommendations to the government for increasing the market share of analgesic generic medicine under non-proprietary names. In this case, the government as the regulator for the generic drugs should make more variations of the form of the analgesic generic medicine under non-proprietary (pill, caplet, capsule, syrup; syrup is better). The analgesic generic medicine under non-proprietary should be distributed not only at the pharmacy but also at the minimarket. It is advisable to inform the doctor or pharmacist to recommend analgesic generic medicine under non-proprietary names to consumers or patients and encourage people to learn about those drugs as so many people do not understand and assume that its quality less than branded drugs. Last, the government should regulate the price of generic medicine under non-proprietary. The price is very cheap compared to branded generic medicine. Increasing the price will be the last choice for the government as its policy will damage the market of analgesic generic branded medicines.

\section{References}

1. M.A. Hassali, A. A., Shafie, S, Jamshed, M.I., Ibrahim, A. Awaisu, Int J Pharm Pract 17, 79-88 (2009)

2. S.Dunne, B. Shannon, C. Dunne, W. Cullen, BMC Pharmacol Toxico, 14, www.ncbi.nlm.nih.gov/pmc/articles/ PMC3579676/ (2013)

3. A. A. Alrasheedy, M. A., Hassali, K. Stewart, D.C.Kong, H. Aljadhey, M. Mohamed Ibrahim, S.K. Al-Tamimi, Patient Intell, 6, 1-29 (2014).

4. S.S. Sansgiry, M. Bhosle, N. Pope, J Pharmaceut Market Manag, 17, 77-91 (2005).

5. N.Danchev, I. Nikolova, editorial of Pharm. Biotechnol, 21 January, 94-99, (2007)

6. K.Thakkar, G. Billa, Front. Pharmacol, 4, 1 (2013).

7. S. Jefferies, M. Saxena, P. Young, Crit Care and Resusc, 14, 74-80, (2012).

8. M. Halme, K. Linden, K. Kääriä, Patient, 2, 243-255 (2009).

9. J. M. Ganther, D. H. Kreling, (2000). J Am Pharm Assoc, 40, 378-383 (2000)

10. J. N. Howard, I. Harris, G. Frank, Z. Kiptanui, J. Qian, R. Hansen, RSAP, 14, 619-627 (2018).

11. M.C. Voicu, Institute for World Economy of the Romanian Academy, 1, 126134 (2013).

12. F.A. Sowunmi, O.C. Omigie, D.T. Daniel, IJDES, 5, 78-86. (2014).

13. V.A.Thiyagaraj. A Study of Consumer Preference towards Branded Tea in Tiruppur City, CGAC, India, 4 (2015).

14. S. Lichtenstein, P. Slovic, The construction of preference, Cambridge (University Press, 
2006)

15. D.I. Hawkins, D. I. Mothersbaugh, Consumer Behaviour: Building Marketing Strategy (11 Ed.) (McGraw-Hill, Irwin, New York, America, 2010).

16. V. Venkatraman, J.A. Clithero, G.J., Fitzsimons, S.A. Huettel, J. Consum. Psychol, 22,143-153 (2012)

17. P.E. Green, A.M. Krieger, Y. Wind, Interfaces, 31, S56-S73 (2001).

18. M. Ryan, S. Farrar, BMJ, 320, 1530-1533. (2000).

19. W.M. Baker, C.C. McGregor, JEB, 75, 149-157. (2000).

20. G. N. Soutar, J.P. Turner, J. P. Int. J. Educ. Manag., 16, 40-45 (2002).

21. C. Hu, S.J. Hiemstra, J. Travel Res, 35, 62-69. (1996).

22. M. Wetzels, K. De Ruyter, J. Lemmink, TQM 11, 307-318. (2000).

23. A. Gustafsson, F. Ekdahl, B. Bergman, TQM, 10, 327-343. (1999)

24. V. Srivastava, N. Pandey, H. Sharma, J. Med. Mark., 9, 319-328. (2009)

25. C. H. Cheng, S, Y. Lin, C.C Tsai, Curr. Urban Stud, 2, 279-290. (2014)

26. M. Wedel, W.A Kamakura, Market segmentation: Conceptual and methodological foundations (Vol. 8). (Springer Science \& Business Media, New York, 2012)

27. S.A.L Mary, A.N. Sivagami, M.U. Rani, ARPN J. Eng. Appl. Sci, 10, 4009-4012 (2015).

28. I. Etikan, S.A. Musa, R.S. Alkassim, AJTAS, 5, 1-4. (2016).

29. R. Myung, Int. J. Ind. Ergon, 32, 341-348. (2003).

30. G.T.Hariyadi, JPEB, 1, 16-32 (2016) 